\title{
Financing and Herd Behaviour in Financial Crises: Investment Decision
}

\author{
Submitted 06/09/20, 1 st revision 15/10/20, 2nd revision 19/11/20, accepted 20/12/20
}

\author{
Raya Panjaitan ${ }^{1}$, Ika Pratiwi Simbolon ${ }^{2}$
}

\begin{abstract}
:
Purpose: The purpose of this study is to provide evidence related to the development of financing and herd behaviour in financial crisis arranging investment decision.

Design/Methodology/Approach: This research is a type of literature study. The methodology used is through descriptive research with the support of theories and the findings from previous studies.

Findings: Capital structure, as has been proven, affects investment decision in financial crisis period, as well as herd behaviour. The firm value can be influenced from the capital decision that gives signals to the market. However, researchers have not yet reached the optimum capital structure. In this paper, the authors find that recent literature on financing and herd behaviour provides some new insights into investment decision during financial crises.

Practical Implications: Authors suggest further directions for increasing the investment strategy in stock market. Evaluating the financing and investment behaviour can lead to the expected return in terms of financial crises.

Originality/Value: The authors' approach can become the basis for investment decision in financial crises. The roles of financing and herd behaviour are really important for investment. There is still less research exploring the role of financial crises in funding decisions and herd behaviour in order to compose investment decision for investor in developed market context.
\end{abstract}

Keywords: Crisis, herd behaviour, financing behaviour, investment decisions.

JEL Codes: G3, G4.

Paper Type: Research Article.

\footnotetext{
${ }^{I}$ Master of Management Department, Universitas HKBP Nommensen Medan, Indonesia, e-mail: raya.panjaitan@uhn.ac.id

${ }^{2}$ Universitas Presiden, Cikarang, Indonesia, e-mail: ika.pratiwi@president.ac.id
} 


\section{Introduction}

Capital structure refers to combination of debt and/or equity in funding operating activities. Therefore, the decision related to this funding varies according to several considerations. Firms provide significant effort to make the decision related to the capital structure. The survival of the firm cannot be guaranteed only from the financial resources. However, lots of mistakes in making decisions in finance would lead to the bankruptcy. Studies on corporate financing decisions (Modigliani and Miller, 1958) have contributed for capital structure development in science.

Herding behaviour has been an interesting discussion to be investigated beside capital structure, especially during crises, due to the fact that causes the fluctuation of the existing financial system. The occurrence of this behaviour in stock market may cause to an invalid assessment of equity. The trading activities may be affected by the expectations related to risk and return, subjectively. As a consequence, this behaviour generates worth information to valuate the equity.

The recent financial crisis has been widely researched by academics (Campello et al., 2010; 2011; Erken et al., 2012), but still rarely do research in exploring the role of crisis in funding decisions and herd behaviour in order to compose investment decision for investors in developed market context. This study fills this gap by providing new insights to investor in order to take successful investment decisions in the stock market.

\section{Literature Review}

Capital structure is a valuable aspect in running the business (Degryse et al., 2010). There are many ways to define the capital structure as shown in the literature. Capital structure in the company consists of the mixture of equity, debt or hybrid securities (Brealey and Myers, 1991). Van-Horn (1989) interprets capital structure as the ratio of debt to the total capital. Pandey (2005) defines capital structure as an option between external and internal financial instruments. Capital structure refers to the composition of debt and/or equity in financing the assets (Titman and Wessels, 1988). From those definitions, we can describe capital structure as the way to raise capital from debt and/or equity to operate the operational activities in the company.

The herding behaviour is the duplication behaviour from the markets' actions, not paying attention to their own information and beliefs (Filip et al., 2015). This is one of the factor for the volatility of the market. Bikhchandani and Sharma (2001) argue that investors are conscious and influenced by the market behaviour. They have emphasized the difference between intentional and false herding behaviour. The intentional herding behaviour is the obvious motive to duplicate market behaviours. Furthermore, false herding behaviour happens when a bunch of investors deal with the same troubles to make decision, but eventually generate the same decisions for trading. 
Devenow and Welch (1996) classify herding behaviour into rational and irrational behaviour. The irrational behaviour refers when investor follows market decision, without equity analysis. The rational behaviour happens when investor generates an optimal decision with rational analysis that can be influenced by external causes.

Researchers have been doing serious investigations of how an individual investor is making investment decisions. Seeking for information an individual investor considers an overview of important suggestions or recommendation in order to make investment decision (Fodness and Murray, 1997). In order to minimize the risk, related information has significant relationship to investment decisions (Lin, 2002). Rational investors must consider all prospects in companies, including financial, operational and growth prospects of investment while creating decisions in investment. Based on research evidence from most of the academics, investors should consider the financing and herd behaviour seriously before take the investment decision especially during financial crises.

\section{Research Method}

The research method in this article is a type of literature study. The analysis is by using descriptive research with the support of theories and the findings from previous studies.

\section{Results}

\subsection{Financing Behaviour}

Danso and Adomako (2014) examine the factors that affect capital structure. They discovered the impact of crises in this matter. This study expands the investigation on capital structure by exploring crisis' effect in capital structure. They found a significant crisis impact on the factors that affect capital structure in Africa. Furthermore, assets tangibility is the most influential determinant in post crises.

Proenca et al. (2014) investigate the factors that affect capital structure in 2007-2010 for the financial crisis on Portuguese SMEs. They found that liquidity, asset structure and profitability are the most important determinants in clarifying the funding system in companies. Companies finance their investments internally, not externally. These findings are related to the theory of pecking order, the external financing cost would generate higher risk. Companies with high tangible assets are expected to issue more debt. In case of default, tangible assets can be used as collateral. These are several findings related to financing behaviour as:

\section{The relationship between profitability to leverage:}

Profitability has the negative relationship to leverage (Danso and Adomako, 2014). Pecking order theory can be applied for profitability in predicting the financing decision. Companies obtain funds the companies with generated funds, which is called internal funding. Meanwhile they obtain funds by issuing debt and/or equity, 
which is referred as external funding (Myers, 1984). Furthermore in studies for SMEs many academics have found a negative effect between profitability to debt ratio (Michaelas et al., 1999; Hall et al., 2000; Mira and Garcia, 2003). Onofrei et al. (2015) also found a negative effect between leverage and profitability. This finding describes enterprises with high profitability tending to fund the operational activities using retained earnings.

\section{The relationship between assets tangibility to leverage:}

Danso and Adomako (2014) found that assets tangibility has positive relationship to leverage. Structure of asset refers to the economic resources owned by firms. Firms that use tangible assets as collateral are expected to issue more debt in case of default (Scott, 1977; Titman and Wessels, 1988). Companies with lots of collateral are easier to access financing sources. Furthermore, the higher liquidation value will be obtained when the companies have lots of tangible assets (Titman and Wessels, 1988; Harris and Raviv, 1990).

The larger tangible assets increases the liquidation value due to collateral in case of default (Harris and Raviv, 1991). The sales of asset increase the value of the company by distributing assets to something more useful when solvent (Morellec, 2001). Asset sales are the cheapest source of funds when the firm deals with financial distress. Companies do not need to require external funds since they have asset sales to finance the operational activities. Onofrei et al. (2015) show that tangibility has the negative effect to capital structure. This is because micro and small enterprises have fewer assets to offer to banks as collateral.

\section{The relationship between liquidity to leverage:}

Danso and Adomako (2014) found that liquidity has the positive relationship to leverage. In measuring the capability of companies to pay the short term debt, companies need to calculate liquidity ratio. Liquidity has a negative effect to debt ratios. Companies will finance investment by having higher liquidity (Ozkan, 2001). Onofrei et al. (2015) find a negative effect between liquidity to capital structure. Furthermore, small enterprises which have more liquidity tend to use equity rather than debts. They also find that liquidity has negative effect to leverage. Goel et al. (2015) analyze Indian machinery firms and find the significant effect between liquidity to leverage. Companies which have higher liabilities tend to hold liquid assets and use long term funds in funding the business. They also find that the determinants of performance are leverage and liquidity.

\subsection{Herd Behaviour}

Herd behaviour refers to the tendency to duplicate the market actions, thus ignoring their own thoughts (Filip et al., 2015). In fact, many investors' respond is based on the trading activities, not based on new information. Herding behaviour happens because investors being sure of others' behavior, possess more information from others than from themselves (Banerjee, 1992). 
Herd behaviour may lead to volatility, bubbles, overvalued and undervalued stocks (Chiang and Zheng, 2010; Bikhchandani and Sharma, 2001). Demand and supply in the market can be influenced by this behaviour. This behaviour occurs from stocks which have high volatility (Balcilar and Demirer, 2015; Shams and Passand, 2015). Most markets around the world have investors who have herd behaviour, especially in Asia (Chiang and Zheng, 2010). Small investors in Hong Kong have this kind of behaviour also (Hon, 2012). Choi and Skiba (2015) found herd behaviour from 41 markets around the world. Mobarek and Mollah (2013) discover this behaviour in emerging countries and developing countries.

Studies suggest that herd mentality play an influential role on decision making as well as on investors' behaviour (Gounaris and Prout, 2009) by the market. In the view of Gounaris and Prout (2009), herd investment is totally suitable in some financial situations. The herding behaviour is an appealing topic, especially after financial crisis hit the economy. The occurrence of this behaviour may cause to invalid valuation of equity. Investors arrange subjective expectations in counting and measuring risk and return.

Chang et al. (2000) analyze herding behaviour for 5 developed markets and 6 emerging markets. Investors have herding behaviour in each country. Hsieh (2013) investigates Taiwanese stock market for the occurrence of this behaviour. After practicing this behaviour, institutional investors receive positive returns. Meanwhile, individual investors receive huge loss from this behaviour. Yao et al. (2014) found the herding behaviour more standing out during market decline or during the crisis period of 1999-2008.

Khan et al. (2011) have investigated investors for the herding behaviour from Great Britain, France, Germany and Italy, especially in size, performance and book value. The applied model was from Salmon and Hwang $(2001 ; 2004 ; 2008)$ which has discovered this behaviour in all markets. Filip et al. (2015) investigated the herding behaviour for upward, downward trends and crises at sector level. They found herd behaviour during a decline period. They composed their decisions based on trend in market. It can be concluded this behaviour is quite different and depends on trend in the market.

\subsection{Investment Decision}

Funding system is really important for the sustainability of firms which gives the ratio between equity and/or debt to operate business. This ratio is really important because stakeholders have different interests and perspectives. It gives signals to the market that will generate firm's value. Capital structure decisions is related to decision in trading activities. For instance, Odit and Chittoo (2008) investigate the effect of leverage of 27 firms on investment decisions. This paper supported previous research findings, e.g., Aivazian et al. (2005), who discovered effect between leverage and investments in Canada. 
Capital structure has been proven to affect investment decision in financial crises period, as well as herd behaviour. Herd behaviour refers to the tendency people have to duplicate the actions of the market, ignoring their own thoughts. Investors' respond is based on trading activities. This will lead the way of trading from investors, and will lead to the stock price as well. Since herd behaviour is significantly proven, a positive perspective is needed from investors for the capital market, especially in the current pandemic condition. This is the reason why we conduct this research, since all of these variables are really important to make investment decision, especially during financial crises period.

\section{Conclusion}

The proposed approach pointed out some crucial findings for investment decision during financial crises. The issue of financing and herd behaviour have been proven to play an important role on investment decisions. Although there is less research exploring the role of financial crises in funding decisions and herd behaviour to compose investment decision the present study claims that research evidence has extensively accepted the relationship between financing and herb behavior in investament decision in the developed market context.

\section{References:}

Aivazian, V.A., Ge, Y., Qiu, J. 2005. The Impact of Leverage on Firm Investment: Canadian Evidence. Journal of Corporate Finance, 11, 277-291.

Balcilar, M., Demirer, Z. 2015. Impact of Global Shocks and Volatility on Herd Behaviour in an Emerging Market: Evidence from Borsa Istanbul. Emerging Markets Finance and Trade, 51.

Banerjee, A. 1992. A Simple Model of Herd Behaviour. Quarterly Journal of Economics, 107, 797-817.

Bikhchandani, S., Sharma, S. 2001. Herd Behaviour in Financial Markets. IMF Staff Papers, 47(3).

Brealey, R., Myers, C. 1991. Principles of Corporate Finance $4^{\text {th }}$ Ed. New York, McGrawHill, U.S.A.

Campello, M., Graham, J.R., Harvey, C.R. 2010. The real effects of financial constraints: Evidence from a financial crisis. Journal of financial Economics, 79(3), 470-487.

Campello, M., Giombona, E., Graham, J.R., Harvey, C.R. 2011. Liquidity Management and Corporate Investment during a Financial Crisis. The Review of Financial Studies, 24(6), 1944-1194.

Chang, E.C., Cheng, J.W., Khorana, A. 2000. An Examination of Herd Behaviour in Equity Markets: An International Perspective. Journal of Banking and Finance, 24(10), 1651-1679.

Chiang, T.C., Zheng, D. 2010. An Empirical Analysis of Herd Behaviour in Global Stock Markets. Journal of Banking and Finance, 34, 1911-1921.

Choi, N., Skiba, H. 2015. Institutional herding in international markets. Journal of Banking and Finance, 55, 246-259.

Danso, A., Adomako, S. 2014. The Financing Behaviour of Firms and Financial Crisis. Managerial Finance, 40(12). 
Degryse, H., Goeij, P., Kappert, P. 2010. The Impact of Firm and Industry Characteristics on Small Firms Capital Structure. Small Bus Econ, 38(4), 431-447.

Devenow, A., Welch, I. 1996. Rational Herding in Financial Economics. European Economic Review, 40(3), 603-615.

Erken, D.H., Hung, M., Matos, P. 2012. Corporate Governance in the 2007-2008 Financial Crisis. Evidence from the Financial Institutions Worldwide. Journal of Corporate Finance, 18(2), 389-411.

Filip, A., Pochea, M., Pece, A. 2015. The Herding Behaviour of Investors in the CEE Stocks Markets. Procedia Economics and Finance, 32, 307-315.

Fodness, D., Murray, B. 1997. Tourist Information Search. Annals of Tourism Research, 24(3), 503-523.

Goel, U., Chadha, S., Sharma, A.K. 2015. Operating Liquidity and Financial Leverage: Evidences from Indian Machinery Industry. Procedia - Social and Behavioural Sciences, 189, 344-350.

Gounaris, K.M., Prout, M.F. 2009. Repairing Relationships and Restoring Trust: Behavioral Finance and the Economic Crisis. Journal of Financial Service Professionals, 63(4).

Hall, G., Hutchinson, P.J., Michaelas, N. 2000. Industry Effects on the Determinants of Unquoted SMEs' Capital Structure. International Journal of the Economics of Business, 7, 297-312.

Harris, M., Raviv, A. 1990. Capital Structure and the Informational Role of Debt. The Journal of Finance, 45(2), 321-349.

Harris, M., Raviv, A. 1991. The Theory of Capital Structure. Journal of Finance, 46(1), $297-$ 355.

Hon, T. 2012. The Behaviour of Small Investors in the Hong Kong Derivatives Markets: A factor analysis. Journal of Risk and Financial Management, 5, 59-77.

Hsieh, S.F. 2013. Individual and Institutional Herding and the Impact on Stock Returns: Evidence from Taiwan Stock Market. International Review of Financial Analysis, 29, 175-188.

Hwang, S., Salmon, M. 2001. A New Measure of Herding and Empirical Evidence. CUBS Financial Econometrics Working Paper, WP01-3, Cass Business School.

Hwang, S., Salmon, M. 2004. Market Stress and Herding. Journal of Empirical Finance, 11, 585-616.

Hwang, S., Salmon, M. 2008. Sentiment and Beta Herding. University of Warwick, Working Paper.

Khan, H., Hassairi, S.A., Viviani, J.L. 2011. Herd Behaviour and Market Stress: The Case of Four European Countries. International Business Research, 4(3), 53-67.

Lin, Q. 2004. Consumers' Information Search When Making Investment Decisions. Financial Services Review, 13(4), 319-332.

Michaelas, N., Chittenden, F., Poutziouris, P. 1999. Financial Policy and Capital Structure Choice in UK SMEs: Empirical Evidence from Company Panel Data. Small Business Economics, 12, 113-130.

Mira, F., Garcia, J. 2003. Pecking Order Versus Trade-Off: An Empirical Approach to the Small and Medium Enterprise Capital Structure. IVIE Working Paper, Universidad Cardenal Herrera.

Mobarek A., Mollah, S. 2013. Cross-Country Analysis of Herd Behaviour in Europe: Evidence from Continental, Nordic and the PIIGS Countries. Journal of International Financial Markets Institutions and Money, 32(1).

Modigliani, F., Miller, H.M. 1958. The Cost of Capital, Corporation Finance and the Theory of Investment. The American Economic Review, 48(3), 261-297.

Morellec, E. 2001. Asset Liquidity, Capital Structure and Secured Debt. Journal of financial Economics, 61(2), 173-206. 
Myers, S.C. 1984. The capital structure puzzle. The Journal of Finance, 39(3), 575-583.

Onofrei, M., Trudose, M.B., Durdureanu, C., Anton, S.G. 2015. Determinant Factors of Firm Leverage: An Empirical Analysis at Iasi Country Level. Procedia Economics and Finance, 20, 460-466.

Ozkan, A. 2001. Determinants of capital structure and adjustment to long run target: evidence from UK company panel data. Journal of Business Finance and Accounting, 28(1-2), 175-198.

Odit, M.P., Chittoo, H.B. 2008. Does Financial Leverage Influence Investment Decisions: The Case of Mauritian Firms. Journal of Business Case Studies, 4(9).

Pandey, I.M. 2005. Financial Mangement 9th Edition. India, Vikas Publishing House Pvt. Ltd.

Proenca, P. 2014. Determinants of Capital Structure and the 2008 Financial Crisis: Evidence from Portuguese SMEs. Procedia - Social and Behavioral Sciences, 150, 182-191

Scott, J. 1977. A Theory of Optimal Capital Structure. Bell Journal of Economics, 32, 33-54.

Shams, S., Passand, A. 2015. The Relationship between Investors Herding and Volatility: Evidence from Tehran Stock Exchange. Iranian Journal for business and economics, 2(3), 1-6.

Titman, S., Wessels, R. 1988. The Determinants of Capital Structure Choice. Journal of Finance, 43(1), 1-19.

Van-Horne, J. 1989. Financial Management and Policy 12th Edition. New Jersey, Upper Saddle River, Prentice-Hall.

Yao, J., Ma, C., Peng He, W. 2014. Investor Herding Behaviour of Chinese Stock Market. International Review of Economics and Finance, 29, 12-29. 